\title{
Urea production and arginine metabolism are reduced in the growth restricted ovine foetus
}

\author{
H. A. de Boo ${ }^{1,2 \dagger}{ }^{+}$, P. L. van Zijl ${ }^{1}$, H. N. Lafeber ${ }^{2}$ and J. E. Harding ${ }^{1}$ \\ ${ }^{1}$ The Liggins Institute, Faculty of Medicine and Health Science, University of Auckland, Private Bag 92019, Auckland, New Zealand; ${ }^{2}$ Department of Pediatrics, \\ Subdivision of Neonatology, Vrije Universiteit Medisch Centrum, De Boelelaan 1117, 1081 HV, Amsterdam, The Netherlands
}

(Received 28 August 2006; Accepted 7 February 2007)

Urea production may be impaired in intrauterine growth restriction (IUGR), increasing the risk of toxic hyperammonaemia after birth. Arginine supplementation stimulates urea production, but its effects in IUGR are unknown. We aimed to determine the effects of IUGR and arginine supplementation on urea production and arginine metabolism in the ovine foetus. Pregnant ewes and their foetuses were catheterised at 110 days of gestation and randomly assigned to control or IUGR groups. IUGR was induced by placental embolisation. At days 120 and 126 of gestation, foetal urea production was determined from $\left[{ }^{14} \mathrm{C}\right]$-urea kinetics and arginine metabolism was determined from the appearance of radioactive metabolites from $[3 \mathrm{H}]$-arginine, both at baseline and in response to arginine or an isonitrogenous mixed amino acid supplementation. Urea production decreased with gestational age in the embolised animals $(13.9 \pm 3.1$ to $11.2 \pm 3.0 \mu \mathrm{mol} / \mathrm{kg}$ per min, $\mathrm{P} \leq 0.05)$ but not in the controls (13.3 \pm 3.5 to $14.8 \pm 6.0 \mu \mathrm{mol} / \mathrm{kg}$ per min). Arginine supplementation increased urea production in both groups, but only at 126 days of gestation (control: $15.0 \pm 8.5$ to $17.0 \pm 9.4 \mu \mathrm{mol} / \mathrm{kg}$ per min; embolised: $11.7 \pm 3.1$ to $14.3 \pm 3.1 \mu \mathrm{mol} / \mathrm{kg}$ per $\min , \mathrm{P} \leq 0.05)$. Embolisation reduced foetal arginine concentrations by $20 \%(\mathrm{P} \leq 0.05)$ while foetal arginine consumption was reduced by $27 \%$ ( $\mathrm{P} \leq 0.05$ ). The proportions of plasma citrulline and hydroxyproline derived from arginine were reduced in the embolised animals. These data suggest that foetal urea production and arginine metabolism are perturbed in late gestation after placental embolisation.

Keywords: arginine, foetus, intrauterine growth restriction, sheep, urea

\section{Introduction}

Intrauterine growth restriction (IUGR) is associated with many changes in foetal and neonatal amino acid metabolism. Plasma concentrations of most amino acids are higher in the foetus than in the mother, indicating an active transport of amino acids across the placenta against a concentration gradient (Cetin et al., 1996). In the growth restricted foetus, concentrations of total $\alpha$-amino nitrogen are reduced, mainly due to reduced concentrations of the branched-chain amino acids (Cetin et al., 1990). In addition, concentrations of many maternal amino acids are elevated in IUGR pregnancies, resulting in reduced foetalto-maternal concentration differences (Cetin et al., 1996). These changes in plasma amino acid concentrations are associated with a reduction in in vivo placental amino acid transport (Paolini et al., 2001). In vitro studies have shown

\footnotetext{
${ }^{\dagger}$ Corresponding author at The Liggins Institute, Faculty of Medicine and Health Science, University of Auckland, Private bag 92019, Auckland, New Zealand. E-mail: n.deboo@auckland.ac.nz
}

reduced activities of system $A$ and taurine transporters in the plasma membranes of placentas from human IUGR pregnancies (Glazier et al., 1997; Norberg et al., 1998). This decrease in substrate supply to the foetus not only results in impaired growth, but may also affect foetal substrate metabolism.

Urea is produced to dispose of excess ammonia, a neurotoxin, which is a by-product of protein oxidation. Although ammonia produced by foetal protein oxidation can be cleared by the mother before birth, after birth impairments in urea production may lead to hyperammonaemia at high protein intakes, associated with neurological damage, lethargy and coma (Msall et al., 1984). Several studies have shown indirect evidence of impaired urea production in both IUGR neonates and foetuses. IUGR neonates are reported to have elevated plasma and urinary $\alpha$-amino nitrogen levels, increased urinary ammonia excretion and decreased urinary urea excretion when compared to normally grown preterm infants (Boehm et al., 1988b and 1991). The differences between the two groups 
are more pronounced with increasing protein intake (Boehm et al., 1988b) and are related to the degree of growth restriction (Boehm et al., 1988a). Furthermore, the normal postnatal development of urea production is delayed in growth restricted infants (Boehm et al., 1991).

Experimental evidence for impaired urea cycle function in IUGR was originally found in guinea-pigs made IUGR by uterine artery ligation, where activities of hepatic urea cycle enzymes were markedly reduced (Lafeber et al., 1979). This was associated with increases in plasma and liver ammonia levels and decreased urea production rates. These data suggest a delay in maturation of the urea cycle associated with IUGR. However, no studies have directly shown in vivo kinetic evidence for reduced urea production in IUGR foetuses or neonates.

One of the key components of the urea cycle is arginine, an amino acid with several anabolic functions. As part of the urea cycle it is a potent stimulator of urea production, and as such it is often administered to patients with inborn errors of the urea cycle to reduce the hyperammonaemia that is symptomatic to the disorder (Leonard, 2001). It may therefore also be useful as a treatment for urea cycle impairment in IUGR. Furthermore, arginine is a metabolically active amino acid which plays a key role in the development of the foetus and placenta (Wu et al., 2004). It is a precursor for many physiologically important compounds such as nitric oxide and polyamines (Wu et al., 2004) and a secretagogue for anabolic hormones such as insulin (Milner et al., 1972; Fowden, 1980), growth hormone (Merimee et al., 1967) and glucagon (Palmer et al., 1975).

This study was designed to investigate the hypotheses that urea production is impaired in the growth-restricted ovine foetus and that production can be stimulated by arginine supplementation. We also investigated the effects of growth restriction on arginine metabolism in the ovine foetus.

\section{Material and methods}

\section{Animal preparation}

Twenty-two pregnant Romney ewes carrying Dorset crossbreed singleton foetuses were housed in individual cages with free access to water. Feed intake was standardised at a maximum of $2.5 \mathrm{~kg}$ pelleted food (65\% lucerne, $30 \%$ barley with the balance composed of molasses, trace elements and limestone. Country Harvest Stockfeeds, Cambridge, NZ) per day. All experiments were approved by the University of Auckland Animal Ethics Committee.

The ewes were randomly assigned to control and embolisation groups and underwent surgery under halothane anesthesia at $110.8 \pm 0.6$ days gestation (dGA, term $=145$ days). Catheters were placed in blood vessels sampling blood supplying and draining both the maternal side of the placenta (a maternal artery (MA) and the uteroovarian vein draining the pregnant horn of the uterus (UOV)) and the foetal side of the placenta (foetal femoral arteries (FA) and the common umbilical vein (UV)). Catheters were also placed in the foetal femoral veins (FV), and a maternal tarsal vein and jugular vein (MV) for administration of infusions and drugs. Growth catheters were inserted subcutaneously around either side of the foetal chest (Harding, 1997). Foetal girth and hock-hoof length were measured. In the IUGR group, the uterine arteries supplying both maternal uterine horns (UA) were also catheterised to allow embolisation of the placenta.

All catheters were flushed with sterile saline containing $10 \mathrm{U}$ per $\mathrm{ml}$ heparin daily for the first 3 days after surgery, and then every other day until post mortem. Foetal chest girth increments were measured twice daily. Ewes were allowed to recover for at least 3 days after surgery before experiments were started.

\section{Embolisation}

In the IUGR group, placental embolisation was begun at $113.8 \pm 0.9 \mathrm{dGA}$. Microspheres (Superose 12, Pharmacia Biotech, Uppsala, Sweden, diluted 1:100, $1 \mathrm{ml}$ per injection) were injected once or twice daily into the uterine arteries. Embolisation was stopped 2 days before the first tracer study, or if the foetal arterial $\mathrm{pO}_{2}$ was $<14 \mathrm{~mm} \mathrm{Hg}$, foetal blood lactate concentration was $>2 \mathrm{mmol} / \mathrm{l}$, or if chest girth had not increased for two consecutive days.

\section{Experimental protocol}

Each animal underwent two tracer studies, one on $120 \mathrm{dGA}$ and one on $126 \mathrm{dGA}$. During each study, foetal urea production and arginine metabolism parameters were measured at baseline, and then during the last hour of a 4-h infusion of either arginine or a mixed amino acid infusion. The order of studies was randomly assigned in each animal. As arginine is a high nitrogen containing amino acid, the isonitrogenous mixed amino acid infusion was used as the control infusion to differentiate the effects of arginine from that of the increased nitrogen load.

For each study, a baseline blood sample was taken from $M A$ and FA catheters. A primed, constant infusion of $\left[{ }^{14} \mathrm{C}\right]$ urea $(0.3 \mu \mathrm{Ci} / \mathrm{min}), \quad L-\left[2,3,4,5-{ }^{3} \mathrm{H}\right]$-arginine $(3.8 \mu \mathrm{Ci} / \mathrm{min}$, American Radiolabelled Chemicals Inc., St Louis, MO, USA) and antipyrine $(0.4 \mathrm{mg} / \mathrm{min})$ was then infused into one of the FV catheters for a total duration of $8 \mathrm{~h}$. Priming doses were equivalent of $100 \mathrm{~min}$ of infusate. Steady-state was reached for all tracers at $180 \mathrm{~min}$, after which five sets of blood samples were simultaneously taken from FA, UV, MA and UOV catheters at 15-min intervals. Immediately after the fifth set of samples an infusion of L-arginine $(12.2 \mu \mathrm{mol} / \mathrm{min})$ or an isonitrogenous control infusion of a mixed amino acid solution (an $89 \%$ dilution of $10 \%$ FreAmine III, Braun Medical Inc., Irvine, USA; control infusion contained $2.44 \mu \mathrm{mol} / \mathrm{min}$ arginine; Table 1) was added to the tracer infusions via the same FV catheter. Both infusates contained $0.98 \mathrm{mmol} / \mathrm{l}$ nitrogen. A new steady-state was reached after another 180 min, after which five additional sets of blood samples were taken. Blood and plasma aliquots were frozen and stored at $-80^{\circ} \mathrm{C}$ until 
Urea and arginine metabolism in IUGR

Table 1 Composition of the amino acid infusate as stated by the manufacturer (10\% FreAmine III, Braun Medical Inc., Irvine, USA) made to an $89.3 \%$ solution with sterile saline

\begin{tabular}{lr}
\hline \hline & $\mathrm{g} / \mathrm{l}$ \\
\hline Alanine & 6.34 \\
Arginine & 8.49 \\
Cysteine & $<0.14$ \\
Glycine & 12.51 \\
Histidine & 2.50 \\
Isoleucine & 6.16 \\
Leucine & 8.13 \\
Lysine & 6.52 \\
Methionine & 4.73 \\
Phenylalanine & 5.00 \\
Proline & 1.00 \\
Serine & 5.27 \\
Threonine & 3.57 \\
Tryptophan & 1.34 \\
Valine & 5.90 \\
\hline \hline
\end{tabular}

further analysis. An additional aliquot was kept on ice for measurement of blood gases on a Chiron M845 blood gas analyser (Chiron Corp. Emeryville, USA) within $15 \mathrm{~min}$ of sampling. At $127 \mathrm{dGA}$ ewes were killed with an overdose of pentobarbitone. The foetus and placenta were removed and weighed and all catheter positions were checked.

\section{Assays}

Antipyrine concentrations were analysed in whole blood by high-performance liquid chromatography (HPLC) as described previously (Pimentel et al., 1986). Urea concentrations were measured by a standard enzymatic colorimetric assay (Kerscher and Ziegenhorn, 1984). Activity of $\left[{ }^{14} \mathrm{C}\right]$-urea was measured in duplicate aliquots of blood deproteinised with $\mathrm{H}_{2} \mathrm{SO}_{4}$ and a $10 \%$ tungstate solution. The supernatant was counted in a dual-channel liquid scintillation counter (Rackbeta 1219, LKB Wallac, Turku, Finland).

Amino acid concentrations were measured in plasma by HPLC using the Waters AccQ.Tag method (Waters Associates, Milford, USA). Our previously published method (Bloomfield et al., 2002) was adapted to allow for collection of glutamate, hydroxyproline, citrulline, arginine, proline and ornithine fractions with a Gilson FC204 fraction collector. Briefly, $100 \mu \mathrm{l}$ plasma was deproteinised with $800 \mu \mathrm{l} 0.02 \mathrm{~mol} / / \mathrm{H}_{2} \mathrm{SO}_{4}$ containing $7.5 \mu \mathrm{mol} / /$ norvaline as internal standard, and $100 \mu \mathrm{l} 5 \%$ tungstate. The supernatant was tagged with borate buffer and AccQ-fluor reagent (6-aminoquinolyl- $N$-hydroxysuccinimidyl carbamate) in acetonitrile. The mixture was incubated at $50^{\circ} \mathrm{C}$ for $10 \mathrm{~min}$, frozen at $-80^{\circ} \mathrm{C}$ and dried down by vacuum evaporation. The residue was resuspended in the mobile phase buffer used for the HPLC method, injected onto the HPLC column and run as described previously (Bloomfield et al., 2002). The collected fractions of arginine metabolites were measured for ${ }^{3} \mathrm{H}$ activity by liquid scintillation counting.
Calculations

Umbilical and uterine blood flows ( $\mathrm{ml} / \mathrm{min}$ ) were calculated from measured antipyrine concentrations according to the Fick principle, as the quotient of the infusion rate and the arterio-venous concentration difference across the placenta (Meschia et al., 1966). Plasma flows were calculated as the product of the blood flow and (1 - fractional haematocrit).

Placental $\left[{ }^{14} \mathrm{C}\right]$-urea clearance was calculated by the steady state diffusion technique, based on the net loss of $\left[{ }^{14} \mathrm{C}\right]$-urea across the placenta relative to the transplacental $\left[{ }^{14} \mathrm{C}\right]$-urea gradient

$$
\begin{gathered}
{\left[{ }^{14} \mathrm{C}\right] \text { - urea clearance }=[(\mathrm{dpmFA}-\mathrm{dpmUV}) /} \\
(\mathrm{dpmFA}-\mathrm{dpmMA})] \times \mathrm{UmBF}
\end{gathered}
$$

where dpmFA, dpmUV and dpmMA are the counts $(\mathrm{dpm} / \mathrm{ml})$ in FA, UV and MA blood, respectively and UmBF is the umbilical blood flow $(\mathrm{ml} / \mathrm{min}$ ) (Gresham et al., 1972).

Foetal urea production rates were calculated as the product of the $\left[{ }^{14} \mathrm{C}\right]$-urea clearance and the transplacental FA MA urea concentration gradient (Gresham et al., 1972).

Percentages of arginine metabolites (glutamate, hydroxyproline, proline, citrulline and ornithine) derived from arginine, were calculated as follows:

$$
\text { conversion }=\left(A A^{*} U V / A R G^{*} F A\right) \times 100
$$

where $A A^{*}$ are the specific activities $(\mathrm{dpm} / \mu \mathrm{mol})$ of the arginine metabolites in plasma from the FA or UV catheters and ARG* is the specific activity of arginine in plasma from the indicated catheter.

Foetal arginine consumption $(\mu \mathrm{mol} / \mathrm{min})$ was determined as follows:

$$
\begin{aligned}
\operatorname{arginine} \text { consumption }= & (I-((d p m F A-d p m U V) \\
& \times U m P F)) / A R G^{*} F A
\end{aligned}
$$

where dpmFA and dpmUV are the ${ }^{3} \mathrm{H}$ counts $(\mathrm{dpm} / \mathrm{ml})$ in the arginine fraction of FA and UV samples, respectively, UmPF is the umbilical plasma flow $(\mathrm{ml} / \mathrm{min})$ and $I$ is the infusion rate of the $\left[{ }^{3} \mathrm{H}\right]$-arginine tracer $(\mathrm{dpm} / \mathrm{min})$.

Daily chest girth increment was determined from the slope of the increment curve using linear regression (Harding, 1997). Daily hock-hoof increment was determined from the difference in hock-hoof length between surgery and post mortem. To estimate foetal weight at $120 \mathrm{dGA}$ in individual foetuses, we used individual foetal growth rates measured as the daily increment in foetal chest girth by the growth catheters. At post mortem there was a strong relationship between foetal chest girth and foetal weight for all animals taken together $\left(r^{2}=0.608, P \leq 0.0001\right)$ as well as for embolised $\left(r^{2}=0.600, P \leq 0.01\right)$ and control groups $\left(r^{2}=0.638, P \leq 0.01\right)$ separately. Furthermore, foetal chest girth increment was linear over the experimental period. Thus for each foetus the total girth increment 
from $120 \mathrm{dGA}$ to post mortem measured by the growth catheters was used to extrapolate back to foetal weight at $120 \mathrm{dGA}$, assuming the same relationship between foetal girth and weight at this age.

\section{Statistical analysis}

The results are presented as mean \pm s.e. For each animal the means of the measurements were calculated during saline infusion and during arginine or amino acid infusion. Baseline differences between the embolised and control groups were analysed with student's $t$-tests. The effect of gestational age was analysed for baseline measurements (saline infusion) only, using repeated measures ANOVA taking into account gestational age (120 dGA and $126 \mathrm{dGA}$ ), group (embolised and control), and group $\times$ gestational age interaction. Similarly, the effects of arginine or amino acid infusion were analysed using repeated measures ANOVA taking into account infusion (before and after), group (embolised and control) and infusion $\times$ group interaction. For those parameters that were not affected by gestational age, data for both days were combined and presented as such. Correlations were determined by simple regression analysis. $P$-values of $\leq 0.05$ were determined to be statistically significant. All statistical analyses were done using Statview Software (SAS Institute, Cary, NC).
Because complete data were not obtained from all animals at both gestational ages, due to technical problems such as catheter failure and inadequate plasma volumes, numbers vary for different results and are specified where appropriate in the tables.

\section{Results}

Foetal characteristics and blood flows

Gestational ages were the same in both groups on both study days and at post mortem (Table 2). Embolisation did not significantly affect foetal weight at post mortem. However, the foetal growth rate was lower in the embolised group, as indicated by $14 \%$ and $20 \%$ reductions in the daily increments in chest girth and hock-hoof length, respectively. Placental weight was also $17 \%$ lower in the embolised group, although this did not reach statistical significance $(P=0.06)$. Baseline uterine blood flow was $27 \%$ lower in the embolised group, but umbilical blood flow was not changed. However, when expressed per kg foetal weight, the uterine blood flow was still significantly lower while the umbilical blood flow was higher in the embolised animals. Placental embolisation significantly reduced foetal arterial and umbilical vein $\mathrm{pO}_{2}$ and increased foetal haematocrit but did not cause hypercapnia or acidaemia at the

Table 2 Gestational ages, placental and foetal measurements, blood flows and foetal blood gases

\begin{tabular}{|c|c|c|c|c|c|c|}
\hline & \multicolumn{2}{|c|}{ Control } & \multirow[b]{2}{*}{$n$} & \multicolumn{2}{|c|}{ Embolised } & \multirow[b]{2}{*}{$n$} \\
\hline & Mean & s.e. & & Mean & s.e. & \\
\hline \multicolumn{7}{|l|}{ Gestational ages (day) } \\
\hline Day 120 & 120.5 & 0.5 & $(11)$ & 120.3 & 0.5 & (11) \\
\hline Day 126 & 126.4 & 0.5 & (9) & 126.1 & 1.1 & (8) \\
\hline Post mortem & 127.0 & 0.9 & $(10)$ & 127.1 & 1.1 & (10) \\
\hline \multicolumn{7}{|l|}{ Measurements } \\
\hline Foetal weight (g) & 3585 & 456 & $(10)$ & 3347 & 668 & (11) \\
\hline Hock-hoof length at surgery $(\mathrm{cm})$ & 13.8 & 0.9 & $(11)$ & 13.8 & 0.7 & (11) \\
\hline Hock-hoof increment (mm/day) & 2.6 & 0.5 & (10) & $2.1^{\mathrm{a}}$ & 0.4 & (10) \\
\hline Chest girth at surgery $(\mathrm{cm})$ & 24.5 & 1.8 & $(11)$ & 25.4 & 1.9 & (11) \\
\hline Chest girth increment (mm/day) & 5.1 & 0.6 & (11) & $4.3^{b}$ & 0.7 & (11) \\
\hline Placental weight $(\mathrm{g})$ & 432 & 83 & (10) & 358 & 73 & (10) \\
\hline \multicolumn{7}{|l|}{ Blood flows ${ }^{\dagger}$} \\
\hline Uterine (ml/min) & 1431 & 215 & (14) & $1041^{c}$ & 306 & (15) \\
\hline Uterine per $\mathrm{kg}$ foetus (ml/kg per min) & 408 & 44 & (13) & $316^{b}$ & 98 & (14) \\
\hline Umbilical (ml/min) & 571 & 130 & (18) & 651 & 141 & (18) \\
\hline Umbilical per $\mathrm{kg}$ foetus (ml/kg per min) & 167 & 40 & (17) & $197^{\mathrm{a}}$ & 43 & (17) \\
\hline \multicolumn{7}{|l|}{ Blood gases $^{\dagger}$} \\
\hline \multicolumn{7}{|l|}{$\mathrm{pO}_{2}(\mathrm{~mm} \mathrm{Hg})$} \\
\hline $\mathrm{FA}^{\ddagger}$ & 19 & 3 & $(20)$ & $16^{\mathrm{b}}$ & 3 & (19) \\
\hline $\mathrm{UV}^{\ddagger}$ & 29 & 5 & (19) & $23^{d}$ & 4 & (18) \\
\hline $\mathrm{UOV}^{\ddagger}$ & 45 & 7 & (15) & 44 & 4 & (15) \\
\hline UOV-UV & 15 & 3 & (14) & $21^{d}$ & 3 & (14) \\
\hline $\mathrm{FA} \mathrm{pCO}_{2}(\mathrm{~mm} \mathrm{Hg})$ & 55 & 3 & (20) & 54 & 3 & (19) \\
\hline FA haematocrit (\%) & 36 & 6 & (17) & $42^{\mathrm{a}}$ & 7 & (19) \\
\hline $\mathrm{FA} \mathrm{pH}$ & 7.35 & 0.02 & (20) & 7.35 & 0.04 & (19) \\
\hline
\end{tabular}

${ }^{\mathrm{a}} P \leq 0.05 ;{ }^{\mathrm{b}} P \leq 0.01 ;{ }^{\mathrm{c}} P \leq 0.001 ;{ }^{\mathrm{d}} P \leq 0.0001$ for comparison between embolised and control animals.

${ }^{\dagger}$ Values for blood flows and blood gases are the baseline results for both study days taken together.

${ }^{\ddagger} \mathrm{FA}$ is foetal artery, UV is umbilical vein, UOV is maternal utero-ovarian vein. 
time of study. The transplacental $\mathrm{pO}_{2}$ gradient (UOV - UV) was $40 \%$ higher in the embolised animals.

Arginine infusion reduced umbilical blood flows to a similar extent in both groups (controls $576 \pm$ 87 to $499 \pm 79 \mathrm{ml} / \mathrm{min}$, embolised $650 \pm 144$ to $570 \pm 185 \mathrm{ml} / \mathrm{min}$, infusion effect $P \leq 0.01$ ). Uterine blood flows were not changed by arginine infusion in either group (controls $1390 \pm 243$ to $1325 \pm 519 \mathrm{ml} / \mathrm{min}$, embolised $1028 \pm 396$ to $1006 \pm 370 \mathrm{ml} / \mathrm{min}$ ). Amino acid infusion did not affect umbilical or uterine blood flows (umbilical: controls $559 \pm 155$ to $602 \pm 122 \mathrm{ml} / \mathrm{min}$, embolised $652 \pm 147$ to $628 \pm 159 \mathrm{ml} / \mathrm{min}$; uterine: controls $1504 \pm 188$ to $1452 \pm 269 \mathrm{ml} / \mathrm{min}$, embolised $1056 \pm 185$ to $1059 \pm 207 \mathrm{ml} / \mathrm{min}$ ). The results were the same when expressed per kg foetus (data not shown)

\section{Urea}

Both foetal and maternal arterial blood urea concentrations tended to be increased in the embolised animals, although they did not reach statistical significance $(P \leq 0.06$ and $P \leq 0.08$, respectively, Table 3 ). The foetal/maternal concentration ratio was not different between the two groups. There were also no differences between the groups in placental urea clearance or foetal urea production, either in absolute value or when expressed per $\mathrm{kg}$ foetal weight. However, foetal urea production rates decreased between study days in embolised but not control animals (controls $13.3 \pm 3.5$ to $14.8 \pm 6.0 \mu \mathrm{mol} / \mathrm{kg}$ per $\mathrm{min}$, embolised $13.9 \pm 3.1$ to $11.2 \pm 3.0 \mu \mathrm{mol} / \mathrm{kg}$ per $\mathrm{min}$, group $\times$ gestational age interaction $P \leq 0.05$ ).

Arginine infusion reduced foetal and maternal arterial blood urea concentrations in both groups (Table 4). The effect on maternal urea concentration was greater in the controls than in the embolised animals. There were no effects of arginine infusion on foetal/maternal concentration ratio, placental urea clearance or foetal urea production rates in either group when the results for both study days were pooled. However, arginine infusion significantly increased foetal urea production in both groups at

Table 3 Baseline values for foetal and maternal blood urea concentrations, foetal urea clearances and foetal urea production rates

\begin{tabular}{|c|c|c|c|c|c|c|}
\hline & \multicolumn{2}{|c|}{ Control } & \multirow[b]{2}{*}{$n$} & \multicolumn{2}{|c|}{ Embolised } & \multirow[b]{2}{*}{$n$} \\
\hline & Mean & s.e. & & Mean & s.e. & \\
\hline$[\mathrm{FA}](\mathrm{mmol} / \mathrm{l})^{\dagger}$ & 4.7 & 0.8 & (20) & 5.3 & 1.0 & (1 \\
\hline$[\mathrm{MA}](\mathrm{mmol} / \mathrm{l})^{\dagger}$ & 3.8 & 1.0 & (20) & .4 & 0.8 & \\
\hline$[\mathrm{FA}]:[\mathrm{MA}]$ & 1.3 & 0.3 & (20) & 1.2 & 0.2 & (17) \\
\hline $\mathrm{Cl}(\mathrm{ml} / \mathrm{min})^{\ddagger}$ & 42.5 & 11.7 & (18) & 47.1 & 13.2 & (17) \\
\hline $\mathrm{Cl}(\mathrm{ml} / \mathrm{kg} / \mathrm{min})$ & 12.3 & 2.9 & (17) & 14.1 & 3.4 & (17) \\
\hline FUP $(\mu \mathrm{mol} / \mathrm{min})^{\ddagger}$ & 48.3 & 15.5 & (18) & 43.7 & 13.9 & $(1$ \\
\hline FUP ( $\mu \mathrm{mol} / \mathrm{kg}$ per min) & 14.0 & 4.7 & (17) & 12.6 & 3.2 & (17) \\
\hline
\end{tabular}

\footnotetext{
${ }^{\dagger}[\mathrm{FA}]$ and $[\mathrm{MA}]$ are the urea concentrations in foetal and maternal arterial blood, respectively.

${ }^{\ddagger} \mathrm{Cl}=$ placental urea clearance; FUP $=$ foetal urea production.
}

$126 \mathrm{dGA}$, but not at $120 \mathrm{dGA}$. Amino acid infusion reduced both foetal and maternal arterial blood urea concentrations (Table 4) but significantly increased the foetal/maternal concentration ratio in both groups. Amino acid infusion did not affect placental urea clearance or foetal urea production rates in either group.

There were no significant correlations between foetal urea production and foetal girth or weight.

\section{Plasma concentrations of arginine metabolites}

Baseline foetal arterial plasma arginine concentrations were $21 \%$ lower in the embolised animals than in the controls (Table 5). There was a significant correlation between umbilical vein arginine concentrations and umbilical vein $\mathrm{pO}_{2}$ for all animals together $\left(r^{2}=0.375, P \leq 0.0001\right)$ as well as for control and embolised groups separately $\left(r^{2}=0.478, \quad P \leq 0.001\right.$ and $r^{2}=0.278, \quad P \leq 0.05$, respectively). Hydroxyproline concentrations also tended to be lower in the embolised foetuses $(P=0.07)$. There were no baseline concentration differences between the two groups for any of the other arginine metabolites.

Arginine infusion increased foetal arterial plasma arginine and ornithine concentrations in both groups (Table 6). Citrulline, glutamate, hydroxyproline and proline concentrations were unchanged. The increase in ornithine concentrations was greater in the embolised animals than in the controls. In both embolised and control animals, infusion of amino acids increased the foetal arterial plasma concentrations of arginine and proline, which were components of the amino acid mixture. Concentrations of citrulline and ornithine also increased in both groups, while glutamate concentrations decreased.

\section{Arginine metabolism}

The percentage of citrulline derived from arginine was significantly reduced and that of hydroxyproline derived from arginine also tended to be reduced $(P=0.07)$ in the embolised foetuses (Table 7). Arginine consumption was also lower in embolised foetuses (control $37 \pm 17 \mu \mathrm{mol} /$ $\mathrm{min}$, embolised $27 \pm 10 \mu \mathrm{mol} / \mathrm{min}, P \leq 0.05)$. Arginine consumption did not correlate with plasma arginine concentrations.

Arginine infusion increased the percentages of hydroxyproline, citrulline and proline derived from radiolabeled arginine in both groups (Table 8). Arginine infusion also increased foetal arginine consumption in both groups (controls $37 \pm 10$ to $48 \pm 14 \mu \mathrm{mol} / \mathrm{min}$, embolised $25 \pm 7$ to $34 \pm 9 \mu \mathrm{mol} / \mathrm{min}$, group effect $P \leq 0.01$, infusion effect $P \leq 0.001$ ). Amino acid infusion increased the percentages of foetal hydroxyproline and citrulline derived from arginine in both groups while reducing the percentage of proline derived from arginine (Table 8). Foetal arginine consumption did not change after amino acid infusion (controls $38 \pm 23$ to $32 \pm 13 \mu \mathrm{mol} / \mathrm{min}$, embolised $25 \pm 6$ to $24 \pm 7 \mu \mathrm{mol} / \mathrm{min})$. 
De Boo, Van Zijl, Lafeber and Harding

Table 4 Effects of arginine or amino acid infusion on foetal and maternal blood urea concentrations, foetal urea clearance and foetal urea production rates

\begin{tabular}{|c|c|c|c|c|c|c|c|c|c|c|c|}
\hline & \multicolumn{4}{|c|}{ Control } & \multirow[b]{3}{*}{$n$} & \multicolumn{4}{|c|}{ Embolised } & \multirow[b]{3}{*}{$n$} & \multirow[b]{3}{*}{ Significance } \\
\hline & \multicolumn{2}{|c|}{ Before } & \multicolumn{2}{|c|}{ After } & & \multicolumn{2}{|c|}{ Before } & \multicolumn{2}{|c|}{ After } & & \\
\hline & Mean & s.e. & Mean & s.e. & & Mean & s.e. & Mean & s.e. & & \\
\hline \multicolumn{12}{|l|}{ Arginine infusion } \\
\hline$[\mathrm{FA}](\mathrm{mmol} / \mathrm{l})^{\dagger}$ & 5.0 & 0.9 & 4.7 & 0.9 & (9) & 5.5 & 0.9 & 5.2 & 0.9 & (8) & c \\
\hline$[\mathrm{MA}](\mathrm{mmol} /)^{\dagger}$ & 4.1 & 0.9 & 3.5 & 0.9 & (9) & 4.6 & 0.9 & 4.3 & 0.9 & (8) & $c *$ \\
\hline$[\mathrm{FA}]:[\mathrm{MA}]$ & 1.3 & 0.2 & 1.4 & 0.2 & (9) & 1.2 & 0.1 & 1.2 & 0.1 & (8) & \\
\hline $\mathrm{Cl}(\mathrm{ml} / \mathrm{min})^{\ddagger}$ & 40.7 & 8.3 & 34.9 & 7.7 & (6) & 45.8 & 8.9 & 44.9 & 7.7 & (8) & \\
\hline $\mathrm{Cl}(\mathrm{ml} / \mathrm{kg}$ per min) & 12.6 & 2.8 & 10.9 & 2.3 & (5) & 13.8 & 2.6 & 13.4 & 2.0 & (8) & \\
\hline FUP $(\mu \mathrm{mol} / \mathrm{min})^{\ddagger}$ & 47.1 & 19.1 & 50.6 & 22.9 & (6) & 42.4 & 12.1 & 44.0 & 16.6 & (8) & \\
\hline FUP ( $\mu \mathrm{mol} / \mathrm{kg}$ per min) & 13.6 & 6.0 & 14.5 & 6.7 & (6) & 12.7 & 3.7 & 12.8 & 4.0 & (8) & \\
\hline $120 \mathrm{dGA}$ & 12.3 & 3.5 & 12.0 & 2.1 & (3) & 13.6 & 4.4 & 11.3 & 4.2 & (4) & \\
\hline $126 \mathrm{dGA}$ & 15.0 & 8.5 & 17.0 & 9.4 & (3) & 11.7 & 3.1 & 14.3 & 3.6 & (4) & a \\
\hline \multicolumn{12}{|l|}{ Amino acid infusion } \\
\hline$[\mathrm{FA}](\mathrm{mmol} / \mathrm{l})^{\dagger}$ & 4.9 & 1.0 & 4.6 & 1.0 & (9) & 5.6 & 0.9 & 5.3 & 0.8 & (8) & a \\
\hline$[\mathrm{MA}](\mathrm{mmol} / \mathrm{l})^{\dagger}$ & 3.7 & 1.0 & 3.4 & 0.9 & (9) & 4.6 & 0.7 & 4.3 & 0.7 & (8) & c A \\
\hline$[\mathrm{FA}]:[\mathrm{MA}]$ & 1.3 & 0.1 & 1.4 & 0.1 & (9) & 1.2 & 0.1 & 1.3 & 0.1 & (8) & c A \\
\hline $\mathrm{Cl}(\mathrm{ml} / \mathrm{min})^{\ddagger}$ & 35.4 & 7.5 & 35.3 & 7.7 & (6) & 46.7 & 17.3 & 40.2 & 15.4 & (8) & \\
\hline $\mathrm{Cl}(\mathrm{ml} / \mathrm{kg}$ per min) & 11.4 & 1.8 & 10.4 & 2.1 & (5) & 13.5 & 3.4 & 11.5 & 2.6 & (8) & \\
\hline FUP $(\mu \mathrm{mol} / \mathrm{min})^{\ddagger}$ & 42.4 & 9.6 & 45.2 & 8.7 & (6) & 41.4 & 12.7 & 41.4 & 15.2 & (8) & \\
\hline FUP ( $\mu \mathrm{mol} / \mathrm{kg}$ per min) & 14.4 & 3.7 & 13.2 & 3.2 & (6) & 12.1 & 2.9 & 12.0 & 3.4 & (8) & \\
\hline
\end{tabular}

${ }^{\mathrm{a}} P \leq 0.05 ;{ }^{c} P \leq 0.001$ for infusion effect in embolised and control animals taken together. ${ }^{A} P \leq 0.05$, for group effect (embolised $v$. control). * $P \leq 0.05$ for infusion $\times$ group interaction.

${ }^{\dagger}[\mathrm{FA}],[\mathrm{MA}]=$ foetal and maternal arterial blood urea concentrations, respectively.

${ }^{\ddagger} \mathrm{Cl}=$ foetal urea clearance; FUP $=$ foetal urea production.

\section{Discussion}

Urea production in the growth restricted foetus

Our study is the first to show direct in vivo kinetic evidence of impaired urea production in the growth-restricted foetus. In embolised animals foetal urea production decreased between 120 and $126 \mathrm{dGA}$ whereas urea production in control animals did not. Urea production is a function of amino acid oxidation and urea cycle function and our study was not designed to distinguish between the two. However, arginine supplementation is known to stimulate urea production, and we observed an increase in foetal urea production after arginine infusion at $126 \mathrm{dGA}$. The increase in foetal urea production was similar in the control and

Table 5 Baseline concentrations ( $\mu \mathrm{mol} / \mathrm{l})$ of arginine metabolites in foetal arterial plasma

\begin{tabular}{lccccc}
\hline \hline & \multicolumn{2}{c}{$\begin{array}{c}\text { Control } \\
(n=20)\end{array}$} & & \multicolumn{2}{c}{$\begin{array}{c}\text { Embolised } \\
(n=18)\end{array}$} \\
\cline { 2 - 3 } \cline { 5 - 6 } & Mean & s.e. & & Mean & s.e. \\
\hline Arginine & 108 & 30 & & $85^{\mathrm{a}}$ & 31 \\
Citrulline & 167 & 33 & & 165 & 38 \\
Glutamate & 73 & 31 & & 75 & 35 \\
Hydroxyproline & 68 & 16 & & 58 & 17 \\
Ornithine & 62 & 17 & & 63 & 19 \\
Proline & 163 & 31 & & 185 & 60 \\
\hline \hline
\end{tabular}

${ }^{\mathrm{a}} P \leq 0.05$ for comparison between control and embolised animals. embolised animals, suggesting that the foetal capacity for urea production was not rate limiting in the embolised animals.

This is in contrast with the original observations by Lafeber et al. (1979) who found a marked decrease in foetal urea cycle enzyme activities in vitro in growth restricted guinea pig foetus. Although our embolised animals showed signs of growth restriction such as changes in growth parameters, hypoxia and an increased transplacental $\mathrm{pO}_{2}$ gradient (Wilkening and Meschia, 1991), there was no reduction in foetal weight at post mortem. The growth restriction in the guinea pig foetuses was very severe ( $<60 \%$ of control weight). Thus it is possible that the growth restriction in our animals was too moderate to detect any in vivo changes in hepatic urea production capacity. Alternatively, there may have been reduced capacity for urea production, but this may still exceeded foetal requirements in vivo.

Due to limited foetal blood volume, only selected compounds could be analysed. Both the foetus and placenta produce ammonia (Holzman et al., 1977), which is largely cleared by the foetal liver via ureagenesis. However, both urea and ammonia also cross the placenta to the maternal circulation, so that in prenatal life, foetal ammonia status is largely determined by maternal rather than foetal capacity for urea production. Maternal urea production was not changed by our experimental procedure. Though it is not implausible that placental embolisation and our 
Urea and arginine metabolism in IUGR

Table 6 The effects of arginine and amino acid infusions on arterial plasma amino acid concentrations (expressed in $\mu$ mol/l)

\begin{tabular}{|c|c|c|c|c|c|c|c|c|c|}
\hline & \multicolumn{4}{|c|}{ Control } & \multicolumn{4}{|c|}{ Embolised } & \multirow[b]{3}{*}{ Significance } \\
\hline & \multicolumn{2}{|c|}{ Before } & \multicolumn{2}{|c|}{ After } & \multicolumn{2}{|c|}{ Before } & \multicolumn{2}{|c|}{ After } & \\
\hline & Mean & s.e. & Mean & s.e. & Mean & s.e. & Mean & s.e. & \\
\hline Arginine infusion & \multicolumn{4}{|c|}{$(n=10)$} & \multicolumn{4}{|c|}{$(n=10)$} & \\
\hline Arginine & 108 & 36 & 198 & 74 & 87 & 40 & 182 & 60 & d \\
\hline Citrulline & 174 & 48 & 169 & 41 & 174 & 50 & 178 & 37 & \\
\hline Glutamate & 69 & 30 & 60 & 33 & 72 & 37 & 76 & 35 & \\
\hline Hydroxyproline & 68 & 21 & 66 & 21 & 59 & 20 & 58 & 16 & \\
\hline Ornithine & 66 & 24 & 112 & 17 & 63 & 17 & 141 & 54 & $c *$ \\
\hline Proline & 161 & 41 & 152 & 29 & 188 & 56 & 189 & 41 & \\
\hline Amino acid infusion & \multicolumn{4}{|c|}{$(n=9)$} & \multicolumn{4}{|c|}{$(n=9)$} & \\
\hline Arginine & 109 & 18 & 131 & 21 & 94 & 26 & 117 & 45 & c \\
\hline Citrulline & 176 & 23 & 190 & 27 & 175 & 36 & 187 & 28 & c \\
\hline Glutamate & 79 & 36 & 67 & 33 & 89 & 35 & 83 & 37 & $\mathrm{~b}$ \\
\hline Hydroxyproline & 73 & 9 & 72 & 6 & 63 & 16 & 65 & 14 & \\
\hline Ornithine & 63 & 12 & 77 & 17 & 67 & 17 & 88 & 34 & $\mathrm{~b}$ \\
\hline Proline & 173 & 19 & 255 & 35 & 177 & 35 & 271 & 59 & d \\
\hline
\end{tabular}

${ }^{\mathrm{b}} P \leq 0.01 ;{ }^{c} P \leq 0.001$ and ${ }^{\mathrm{d}} P \leq 0.0001$ for infusion effect in both control and embolised animals together. ${ }^{*} P \leq 0.05$ for infusion $\times$ group interaction.

treatments would have an effect on foetal ammonia status, foetal urea production rates were deemed to be a more important outcome than foetal ammonia concentrations. It was therefore decided that foetal ammonia levels would not be measured.

Arginine infusion increased foetal urea production at $126 \mathrm{dGA}$, but not at $120 \mathrm{dGA}$. Arginine might increase urea production in two ways: firstly, the supplemented arginine can directly be hydrolysed into ornithine and urea by arginase activity, an enzyme that is present in many tissue types (Wu and Morris, 1998). Secondly, the additional ornithine produced in this reaction also stimulates the formation of new urea from ammonia. Our study was not designed to distinguish between the two pathways. One recent study has shown that placental arginase activity peaks relatively early in ovine gestation, around $60 \mathrm{dGA}$ (Kwon et al., 2003) but others have reported increasing foetal hepatic arginase activity with increased gestation (Rattenbury et al., 1980). In human foetuses, urea cycle enzyme activities also increase throughout gestation (Mukarram Ali Baig et al., 1992). Thus increased urea pro-

Table 7 Effects of placental embolisation on baseline conversions of arginine into its metabolites, expressed as the percentage of the metabolite derived from arginine (expressed in $\mu \mathrm{mol} / \mathrm{l})$

\begin{tabular}{lrrrrr}
\hline \hline & \multicolumn{2}{c}{$\begin{array}{c}\text { Controls } \\
(n=19)\end{array}$} & & \multicolumn{2}{c}{$\begin{array}{c}\text { Embolised } \\
(n=16)\end{array}$} \\
\cline { 2 - 3 } & Mean & s.e. & & Mean & s.e. \\
\hline Glutamate & 1.7 & 3.0 & & 2.4 & 2.5 \\
Hydroxyproline & 17.6 & 14.5 & & 10.6 & 4.4 \\
Citrulline & 20.2 & 12.0 & & $13.2^{\mathrm{a}}$ & 2.4 \\
Proline & 7.2 & 2.9 & & 6.0 & 2.0 \\
\hline \hline
\end{tabular}

a $P \leq 0.05$ for comparison between embolised and control animals. duction in response to arginine infusion between 120 and $126 \mathrm{dGA}$ might be due to increased activity of either or both of these pathways. However it is unlikely that all of the infused arginine was directly hydrolysed via the arginase pathway in the foetus even at $126 \mathrm{dGA}$, since the increase in foetal urea production would account for only approximately one-third of the arginine infusion rate.

\section{Foetal urea concentrations}

Embolisation tended to increase both foetal and maternal urea concentrations, in spite of the lower foetal urea production rates in the embolised group. As urea crosses the placenta by simple diffusion down a concentration gradient, the maternal urea concentrations are an important determinant of foetal urea concentrations, regardless of foetal urea production. It can be hypothesised that in the embolised pregnancies there was a decreased foetal demand for amino acids due to a reduced foetal growth rate as well as impaired placental amino acid transport, reducing the amount of amino acids transported to the foetus. This may have resulted in increased maternal amino acid oxidation and urea production and thus a decrease in the foetal to maternal concentration gradient and an increase in foetal urea concentrations, consistent with our findings.

In contrast, arginine infusion reduced foetal and maternal urea concentrations in spite of an increase in foetal urea production. Again, the change in maternal urea concentrations was greater than the change in the foetal concentrations and the resulting increase in the foetal to maternal concentration ratio suggests that the change in foetal urea concentration is secondary to the change in the maternal concentration, independent of foetal urea production. This change in maternal urea concentrations may again reflect altered demand for maternal amino 
De Boo, Van Zijl, Lafeber and Harding

Table 8 Effects of arginine and amino acid infusion on arginine conversions into its metabolites expressed as the percentage of the metabolite derived from arginine (expressed in $\mu \mathrm{mol} / \mathrm{l})$

\begin{tabular}{|c|c|c|c|c|c|c|c|c|c|}
\hline & \multicolumn{4}{|c|}{ Control $(n=7)$} & \multicolumn{4}{|c|}{ Embolised $(n=8)$} & \multirow[b]{3}{*}{ Significance } \\
\hline & \multicolumn{2}{|c|}{ Before } & \multicolumn{2}{|c|}{ After } & \multicolumn{2}{|c|}{ Before } & \multicolumn{2}{|c|}{ After } & \\
\hline & Mean & s.e. & Mean & s.e. & Mean & s.e. & Mean & s.e. & \\
\hline \multicolumn{10}{|l|}{ Arginine infusion } \\
\hline Glutamate & 1.4 & 3.1 & 3.5 & 3.3 & 2.7 & 3.1 & 3.8 & 3.9 & a \\
\hline Hydroxyproline & 13.5 & 3.4 & 24.6 & 9.1 & 9.8 & 4.5 & 22.3 & 11.9 & d \\
\hline Citrulline & 20.5 & 11.1 & 33.4 & 23.7 & 12.7 & 2.7 & 23.6 & 4.9 & d \\
\hline Proline & 6.3 & 2.1 & 9.7 & 3.0 & 6.0 & 2.1 & 9.3 & 3.5 & d \\
\hline \multicolumn{10}{|l|}{ Amino acid infusion } \\
\hline Glutamate & 0.9 & 2.5 & 2.0 & 2.4 & 2.2 & 1.7 & 3.3 & 5.7 & \\
\hline Hydroxyproline & 17.1 & 8.1 & 18.8 & 7.4 & 11.6 & 4.3 & 14.2 & 5.5 & $\mathrm{~b}$ \\
\hline Citrulline & 20.7 & 12.0 & 21.6 & 10.5 & 13.7 & 2.1 & 17.4 & 3.0 & $\mathrm{~b}$ \\
\hline Proline & 7.4 & 3.4 & 6.1 & 2.5 & 6.0 & 2.0 & 5.4 & 1.7 & a \\
\hline
\end{tabular}

${ }^{\mathrm{a}} P \leq 0.05 ;{ }^{\mathrm{b}} P \leq 0.01 ;{ }^{\mathrm{d}} P \leq 0.0001$ for infusion effect in control and embolised animals together.

acids. Arginine infusion stimulates protein accretion in both control and embolised animals (de Boo et al., 2005) which would increase foetal demand for amino acids from the maternal circulation, thus potentially decreasing maternal amino acid oxidation and urea production. Amino acid infusion had similar effects.

\section{Arginine metabolism}

Arginine concentrations were approximately $20 \%$ lower in the embolised animals than in the control animals. Studies in human IUGR pregnancies have shown no reduction in the placental microvillous membrane activity of the two transporter types, $\mathrm{y}^{+}$and $\mathrm{y}^{+} \mathrm{L}$, that are responsible for the transplacental transport of arginine (Ayuk et al., 2002). However, $\mathrm{y}^{+} \mathrm{L}$ transporter activity is dependent on the oxygenation of the uteroplacental unit (Radaelli et al., 2002). The embolised foetuses in our study had lower arterial $\mathrm{pO}_{2}$ values and we found a strong correlation between umbilical venous $\mathrm{pO}_{2}$ and arginine concentrations. The lower arginine concentrations in the embolised group were therefore likely to be the result of reduced placental transport associated with reduced placental oxygenation.

Total foetal arginine consumption rates were $27 \%$ lower in the embolised animals, and the fractions of citrulline and hydroxyproline derived from arginine were also lower. Hydroxyproline is formed from proline during the synthesis of collagen, the main structural protein in the body (Yang et al., 2004), thus the reduction in the proportion of hydroxyproline synthesis from arginine in the embolised animals may indicate reduced collagen synthetic rates.

Citrulline can be produced from arginine in two ways. Firstly, it can be produced through activity of the urea cycle enzymes arginase, which produces ornithine from arginine and is universally present in many tissue types, and carbamoylphosphate synthase and ornithine carbamoyltransferase, which produce citrulline from ornithine. Secondly, citrulline is a by-product of the synthesis of nitric oxide (NO) from arginine, a reaction that is catalysed by nitric oxide synthase. NO is an endothelium derived vasodilator, and as such is involved in the distribution of blood flow throughout the body. Due to the presence of trace amounts of labeled ornithine in the arginine tracer, which was not metabolised (unpublished observations), we have no reliable results for ornithine production rates. Therefore we cannot speculate on the extent of citrulline production from ornithine. However, we found increased umbilical blood flows in the embolised animals, which may indicate a reduction in foetal NO production, causing vasoconstriction in the foetal blood vessels and redistribution of blood flow away from the foetus towards the placenta. This may be a means of compensation for the reduced nutrient supply caused by the reduced uterine blood flow after embolisation.

Similarly, arginine infusion caused an decrease in umbilical blood flow and an increase in the proportion of foetal citrulline produced from arginine, which may indicate an increase in foetal NO production, causing vasodilation in the foetal blood vessels and redistribution the blood flow away from the placenta and towards the foetus.

\section{Summary}

This study provides the first in vivo kinetic evidence of decreased foetal urea production in late gestation after placental embolisation. Arginine infusion increased urea production to a similar extent in both control and embolised animals at $126 \mathrm{dGA}$ but not at $120 \mathrm{dGA}$, suggesting that the foetal capacity for urea production increased with gestation, but was not limiting in the embolised animals. Production of citrulline and hydroxyproline from arginine was reduced in the embolised animals. These data suggest that foetal urea production and arginine metabolism are perturbed in late gestation after placental embolisation.

\section{Acknowledgements}

We thank Ms Toni Smith for her excellent technical assistance with the animal studies and Ms Janine Street for the urea assays. This project was supported by grants from the Nutricia 
Research Foundation and the Health Research Council of New Zealand. HA de Boo received a personal scholarship from the Ter Meulen Fonds.

\section{References}

Ayuk PT, Theophanous D, D'Souza SW, Sibley CP and Glazier JD 2002. L-arginine transport by the microvillous plasma membrane of the syncytiotrophoblast from human placenta in relation to nitric oxide production: effects of gestation, preeclampsia, and intrauterine growth restriction. Journal of Clinical Endocrinology \& Metabolism 87, 747-751.

Bloomfield FH, van Zijl PL, Bauer MK and Harding JE 2002. Effects of intrauterine growth restriction and intraamniotic insulin-like growth factor-I treatment on blood and amniotic fluid concentrations and on fetal gut uptake of amino acids in late-gestation ovine fetuses. Journal of Pediatric Gastroenterology \& Nutrition 35, 287-297.

Boehm G, Gedlu E, Muller MD, Beyreiss K and Raiha NC 1991. Postnatal development of urea- and ammonia-excretion in urine of very-lowbirth-weight infants small for gestational age. Acta Paediatrica Hungarica 31, 31-45.

Boehm G, Senger H, Braun W, Beyreiss K and Raiha NC 1988a. Metabolic differences between AGA- and SGA-infants of very low birthweight. I. Relationship to intrauterine growth retardation. Acta Paediatrica Scandinavica $77,19-23$.

Boehm G, Senger H, Muller D, Beyreiss K and Raiha NC 1988b. Metabolic differences between AGA- and SGA-infants of very low birthweight. II. Relationship to protein intake. Acta Paediatrica Scandinavica 77, 642-646.

Cetin I, Corbetta C, Sereni LP, Marconi AM, Bozzetti P, Pardi G and Battaglia FC 1990. Umbilical amino acid concentrations in normal and growth-retarded fetuses sampled in utero by cordocentesis. American Journal of Obstetrics \& Gynecology 162, 253-261.

Cetin I, Ronzoni S, Marconi AM, Perugino G, Corbetta C, Battaglia FC and Pardi G 1996. Maternal concentrations and fetal-maternal concentration differences of plasma amino acids in normal and intrauterine growthrestricted pregnancies. American Journal of Obstetrics \& Gynecology 174, 1575-1583.

de Boo HA, van Zijl PL, Smith DEC, Kulik W, Lafeber HN and Harding JE 2005. Arginine and mixed amino acids increase protein accretion in the growth restricted and normal ovine fetus by different mechanisms. Pediatric Research 58, 270-277.

Fowden AL 1980. Effects of arginine and glucose on the release of insulin in the sheep fetus. Journal of Endocrinology 85, 121-129.

Glazier JD, Cetin I, Perugino G, Ronzoni S, Grey AM, Mahendran D, Marconi AM, Pardi G and Sibley CP 1997. Association between the activity of the system $A$ amino acid transporter in the microvillous plasma membrane of the human placenta and severity of fetal compromise in intrauterine growth restriction. Pediatric Research 42, 514-519.

Gresham EL, James EJ, Raye JR, Battaglia FC, Makowski EL and Meschia $\mathrm{G}$ 1972. Production and excretion of urea by the fetal lamb. Pediatrics 50, 372-379.

Harding JE 1997. Prior growth rate determines the fetal growth response to acute maternal undernutrition in fetal sheep of late gestation. Prenatal and Neonatal Medicine 2, 300-309.

Holzman IR, Lemons JA, Meschia G and Battaglia FC 1977. Ammonia production by the pregnant uterus. Proceedings of the Society for Experimental Biology \& Medicine 156, 27-30.
Kerscher $L$ and Ziegenhorn J 1984. Urea. In Methods of enzymatic analysis (ed. HU Bergmeyer), pp. 444-453. Verlag Chemie, Weinheim.

Kwon H, Wu G, Bazer FW and Spencer TE 2003. Developmental changes in polyamine levels and synthesis in the ovine conceptus. Biology of Reproduction 69, 1626-1634.

Lafeber HN, Jones CT and Rolph TP 1979. Some of the consequences of intrauterine growth retardation. In Nutrition and metabolism of the fetus and infant (ed. HKA Visser), pp. 43-63. Martinus Nijhof Publishers, The Hague.

Leonard JV 2001. The nutritional management of urea cycle disorders. The Journal of Pediatrics 138, S40-S44.

Merimee TJ, Rabinowitz D, Riggs L, Burgess JA, Rimoin DL and McKusick VA 1967. Plasma growth hormone after arginine infusion. Clinical experiences. The New England Journal of Medicine 276, 434-439.

Meschia G, Cotter JR, Makowski EL and Barron DH 1966. Simultaneous measurement of uterine and umbilical blood flows and oxygen uptakes. Quarterly Journal of Experimental Physiology 52, 1-18.

Milner RD, Ashworth MA and Barson AJ 1972. Insulin release from human foetal pancreas in response to glucose, leucine and arginine. Journal of Endocrinology 52, 497-505.

Msall M, Batshaw ML, Suss R, Brusilow SW and Mellits ED 1984. Neurologic outcome in children with inborn errors of urea synthesis. Outcome of ureacycle enzymopathies. The New England Journal of Medicine 310, 1500-1505.

Mukarram Ali Baig M, Habibullah CM, Swamy M, Hassan I, Taher-Uz I, Ayesha Q and Devi BG 1992. Studies on urea cycle enzyme levels in the human fetal liver at different gestational ages. Pediatric Research 31, 143-145.

Norberg S, Powell TL and Jansson T 1998. Intrauterine growth restriction is associated with a reduced activity of placental taurine transporters. Pediatric Research 44, 233-238.

Palmer JP, Walter RM and Ensinck JW 1975. Arginine-stimulated acute phase of insulin and glucagon secretion. I. in normal man. Diabetes 24, 735-740.

Paolini CL, Meschia G, Fennessey PV, Pike AW, Teng C, Battaglia FC and Wilkening RB 2001. An in vivo study of ovine placental transport of essential amino acids. American Journal of Physiology - Endocrinology and Metabolism 280, E31-E39.

Pimentel G, Figueroa JP, Mitchell MD, Massmann A and Nathanielsz PW 1986. Effect of fetal and maternal intravascular antipyrine infusion on maternal plasma prostaglandin concentrations in the pregnant sheep at 104 to 127 days' gestation. American Journal of Obstetrics \& Gynecology 155, 1181-1185.

Radaelli T, Cetin I, Ayuk PT, Glazier JD, Pardi G and Sibley CP 2002. Cationic amino acid transporter activity in the syncytiotrophoblast microvillous plasma membrane and oxygenation of the uteroplacental unit. Placenta 23, S69-S74.

Rattenbury JM, Jeacock MK and Shepherd DA 1980. Urea synthesis in the liver and kidney of developing sheep. Biochimica et Biophysica Acta 630, 210-219.

Wilkening RB and Meschia G 1991. Effect of occluding one umbilical artery on placental oxygen transport. American Journal of Physiology - Heart and Circulatory Physiology 260, H1319-H1325.

Wu G and Morris SM Jr 1998. Arginine metabolism: nitric oxide and beyond. Biochemical Journal 336, 1-17.

Wu G, Bazer FW, Cudd TA, Meininger CJ and Spencer TE 2004. Maternal nutrition and fetal development. The Journal of Nutrition 134, 2169-2172.

Yang C, Hillas PJ, Baez JA, Nokelainen M, Balan J, Tang J, Spiro R and Polarek JW 2004. The application of recombinant human collagen in tissue engineering. BioDrugs 18, 103-119. 